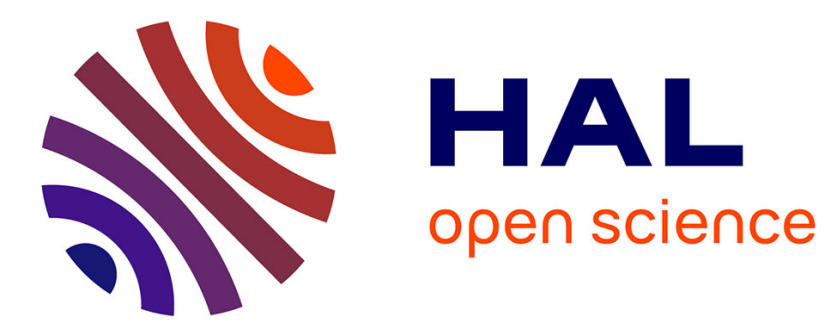

\title{
Migration of antimony from PET bottles into beverages: Determination of the activation energy of diffusion and migration modelling compared to literature data
}

Frank Welle, Roland Franz

\section{- To cite this version:}

Frank Welle, Roland Franz. Migration of antimony from PET bottles into beverages: Determination of the activation energy of diffusion and migration modelling compared to literature data. Food Additives and Contaminants, 2010, 28 (1), pp.115. 10.1080/19440049.2010.530296 . hal-00654489

\author{
HAL Id: hal-00654489 \\ https://hal.science/hal-00654489
}

Submitted on 22 Dec 2011

HAL is a multi-disciplinary open access archive for the deposit and dissemination of scientific research documents, whether they are published or not. The documents may come from teaching and research institutions in France or abroad, or from public or private research centers.
L'archive ouverte pluridisciplinaire HAL, est destinée au dépôt et à la diffusion de documents scientifiques de niveau recherche, publiés ou non, émanant des établissements d'enseignement et de recherche français ou étrangers, des laboratoires publics ou privés. 


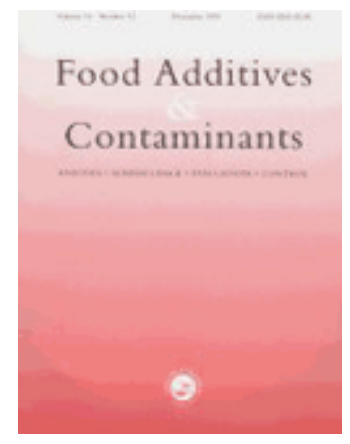

Migration of antimony from PET bottles into beverages: Determination of the activation energy of diffusion and migration modelling compared to literature data

\begin{tabular}{|r|l|}
\hline Journal: & Food Additives and Contaminants \\
\hline Manuscript ID: & TFAC-2010-187.R1 \\
\hline Manuscript Type: & Original Research Paper \\
\hline $\begin{array}{r}\text { Date Submitted by the } \\
\text { Author: }\end{array}$ & $20-$ Sep-2010 \\
\hline Complete List of Authors: & $\begin{array}{l}\text { Welle, Frank; Fraunhofer IVV } \\
\text { Franz, Roland; Fraunhofer IVV }\end{array}$ \\
\hline Methods/Techniques: & Exposure modelling, Metals analysis - ICP/MS, Quality assurance \\
\hline Additives/Contaminants: & Migration - diffusion, Heavy metals, Packaging - PET \\
\hline Food Types: & Beverages, Fruit juices, Drinking water \\
\hline &
\end{tabular}

\section{SCHOLARONE ${ }^{m}$ Manuscripts}


Migration of antimony from PET bottles into beverages: Determination of the activation energy of diffusion and migration modelling compared to literature data

Frank Welle* and Roland Franz

Fraunhofer Institute for Process Engineering and Packaging, IVV Giggenhauser Straße 35, 85354 Freising, Germany

*Correspondence: welle@ivv.fraunhofer.de 


\section{Abstract}

Plastics bottles made from polyethylene terephthalate (PET) are increasingly used for soft drinks, mineral water, juices and beer. In this study a literature review is presented concerning antimony levels found both in PET materials as well as in foods and food simulants. On the other hand, 67 PET samples from the European bottle market were investigated for their residual antimony concentrations. A mean value of $224 \pm 32 \mathrm{mg} / \mathrm{kg}$ was found, the median was $220 \mathrm{mg} / \mathrm{kg}$. Diffusion coefficients for antimony in PET bottle materials were experimentally determined at different temperature between $105^{\circ} \mathrm{C}$ and $150{ }^{\circ} \mathrm{C}$. From these data the activation energy of diffusion for antimony species from the PET bottle wall into beverages and food simulants was calculated. The obtained value $189 \mathrm{~kJ} \mathrm{~mol}^{-1}$ was found to be in good agreement with published data on PET microwave trays $\left(184 \mathrm{~kJ} \mathrm{~mol}^{-1}\right)$. Based on these results the migration of antimony into beverages was predicted by mathematical migration modelling for different surface/volume ratios and antimony bottle wall concentrations. The results were compared to literature data as well as international legal limits and guidelines values for drinking water as well as migration limit set from food packaging legislation. It was concluded that antimony levels in beverages due to migration from PET bottles manufactured according to state-ofthe-art can never reach nor exceed the European specific migration limit of $40 \mu \mathrm{g} / \mathrm{kg}$. Maximum migration levels caused by room temperature storage even after 3 years will never be essentially higher than $2.5 \mu \mathrm{g} / \mathrm{kg}$ and will be in any case below the European limit of $5 \mu \mathrm{g} / \mathrm{kg}$ for drinking water. The results of our study confirm that the exposure of the consumer by antimony migration from PET bottles into beverages and even into edible oils reaches approximately $1 \%$ of the current TDI established by WHO. Having substantiated such low antimony levels in PET bottled beverages the often addressed question on estrogenic effects caused by antimony from PET bottles appears to be groundless.

Keywords:- Plastic bottles, migration, polyethylene terephthalate (PET), antimony, diffusion coefficients, activation energy of diffusion, juices, mineral water 


\section{Introduction}

Plastics bottles made from polyethylene terephthalate (PET) are increasingly used for beverages like soft drinks, mineral water, juices and beer. In 2007 the world-wide consumption of PET was about 15 Mio. tons (Plastics Europe 2008). Most of the PET resin was sold as food grade material for beverage packaging. In comparison to other packaging plastics, PET is one of the most inert polymers with good barrier properties against moisture, oxygen and carbon dioxide and with a very low migration tendency of its constituents. However, migration of substances from PET bottles into beverages is not completely negligible. Polymer additives, catalyst residues, degradation products, polymerisation side-product or residual monomers are potential migrants. Mass transfer of a migrant from PET polymer into food depends on several factors such as storage time and temperature, concentration of the migrant in the polymer, type and nature of the migrant and its solubility in food. Migration kinetics of several organic impurities and additives in PET have been investigated in systematic migration studies within the last years. Target migrants were for instance acetaldehyde (Ewender et al 2003), the PET cyclic trimer (Begley and Hollifield 1990) or UV blocking additives Tinuvin 234 and Tinuvin 1577 (Begley et al 2004).

Recently, we investigated the migration of organic model compounds into food simulants and beverages such as soft drinks, flavoured waters and juices to establish the migration determining mass transfer parameters (Franz and Welle 2008). As suitable model migrants, as more volatile compounds toluene and chlorobenzene and as less volatile substances phenyl cyclohexane, benzophenone and methyl stearate were used. The results of this study showed that food simulants like $50 \%$ or $95 \%$ ethanol which cause a slight swelling of the PET polymer matrix do increase the migration significantly in comparison to usual beverages. Such high alcoholic simulants can therefore be considered as worse case test media for compliance testing of PET beverage bottles. On the other hand, the aqueous food simulants $3 \%$ acetic acid, water and $10 \%$ ethanol lead in many cases to an underestimation of migration of organic constituents in comparison to beverages. 
One important conclusion of this study was that the migration of organic compounds from the bottle wall into beverages is largely controlled by the diffusion coefficient in the polymer. The partition coefficient which represents the ratio between the concentration of a migrant in the polymer and in the food at the equilibrium plays a minor role only. Therefore, for the predictive evaluation of compliance of PET bottles knowledge of the diffusion coefficients of potential migrants is highly important since it allows to calculate the concentration of a migrant in the foodstuff under certain storage conditions.

Not only organic components are able to migrate from the PET bottle into the bottled beverages but also inorganic substances, for instance residues from polymerisation catalysts can leach from the polymer. The release of inorganic substances from beverage bottles made of glass versus PET has been investigated in a few studies (see literature review below). Very recently, a comprehensive study was published in which drinking water contamination from bottle materials was investigated for 57 chemical elements (Reimann et al 2010). In this study the only element which was higher concentrated in PET bottled water was antimony with a 21-fold concentration over glass. All other elements were either comparable in PET and glass bottled water or considerably higher in glass bottled water. These parameters were in particular Cer (19-fold higher in glass), Lead (14-fold), Aluminium (7-fold) and other. The higher concentrations of antimony in PET bottle water is expected, because antimony trioxide $\left(\mathrm{Sb}_{2} \mathrm{O}_{3}\right)$ or it's reaction product with ethylene glycol is widely used as polycondensation catalyst for manufacturing of PET. The antimony catalyst offers a high catalytic activity and has a low tendency to catalyse side reactions. In addition antimony does not engender undesirable colours (Duh 2002). In principle the polymerisation catalyst remains in the PET polymer.

Within the last decade, several studies on the migration of antimony from PET bottles into beverages and on exposure levels in mineral water, soft drinks and juices have been published (see literature review below). In addition antimony, in the form of the chemical species antimony chloride, has been reported to possess weak estrogenicity (Choe et al 2003) and since then numerous papers have been published in which a link between antimony from PET and possible estrogenic 
effects were discussed (see for example Sax 2010). In conclusion, antimony must be considered as the most important inorganic species which may migrate from the PET bottle wall into the beverages.

For prediction of exposure levels, the diffusion coefficients of antimony in PET at different temperatures are helpful. Haldimann et al (2007) determined the migration of antimony into ready-to-eat meals under microwave or oven-cooking conditions. PET trays for ready-to-eat meals consist of crystalline PET. In a second study (Alt et al 2008) the diffusion coefficients of antimony in PET were determined from $45^{\circ} \mathrm{C}$ up to $150{ }^{\circ} \mathrm{C}$, most probably also crystalline PET trays. In comparison to microwave trays, PET beverage bottles have typically a significantly lower crystallinity of about $30 \%$ to $40 \%$, which might influence the diffusion coefficients of antimony.

Since measured or predicted values should or need to be compared with established concentration limits the following is a short review of existing regulatory antimony levels.. According to the German BfR recommendations the maximum concentration of antimony in PET bottles should not exceed $350 \mathrm{mg} / \mathrm{kg}$ (BfR 2010). Limits or guideline values for antimony in drinking water are specified in several countries: $5 \mu \mathrm{g} / \mathrm{kg}$ in Europe (EU 2003), $6 \mu \mathrm{g} / \mathrm{kg}$ in the United States and Canada (US EPA 2009, Canada 2008), $15 \mu \mathrm{g} / \mathrm{kg}$ in Japan (Japan 2003) and $20 \mu \mathrm{g} / \mathrm{kg}$ by the World Health Organisation (WHO 2003). These drinking water limits are often used for the evaluation of antimony concentrations found in bottled beverages. From a legal point of view, however, these limits are applicable for drinking water itself before it is bottled. In PET packed beverages the specific migration limits according to packaging legislation are applicable. This is in Europe $40 \mu \mathrm{g} / \mathrm{kg}$ (EU 2002) and in Japan $50 \mu \mathrm{g} / \mathrm{kg}$ (JETRO 2009). The US Food and Drug Administration (FDA) has not specified a special migration limit for antimony from PET packaging materials. Existing toxicological data suggest for humans a tolerable daily intake (TDI) for antimony of $6 \mathrm{\mu g} \mathrm{kg}^{-1}$ body weight (WHO 2003) which means that a daily consumption of $360 \mu \mathrm{g}$ may be tolerable for an adult person with $60 \mathrm{~kg}$ body weight.

The objective of this study was: To determine experimentally the diffusion characteristics, i.e. activation energy and diffusion coefficients of antimony in PET 
beverage bottle materials. For this purpose it was also necessary to measure and compile the typical concentration range of antimony present in PET beverage bottles on the European market. Based on the results, the migration of antimony into beverages should be predicted by mathematical modelling for different surface/volume ratios and antimony bottle wall concentrations. Finally these results should be compared with data obtained from a comprehensive literature review on antimony diffusion in and migration from PET materials in contact with packaged beverages.

\section{Literature review}

Numerous studies have been published either on the antimony content of PET bottle material or on antimony concentrations in beverages like mineral water, soft drinks and juices. According to Duh (2002), antimony concentrations in PET plastics range between $190 \mathrm{mg} / \mathrm{kg}$ to $300 \mathrm{mg} / \mathrm{kg}$. In the literature, some other studies can be found which confirm this concentration range where antimony has been used as catalyst. The experimentally determined antimony concentrations found in PET bottles from literature data are summarized in Table 1. Much more papers have been published on investigations to which extend antimony might migrate from the bottle wall into the beverage. A compilation of these literature data for antimony concentrations found in packaged beverages and in food simulants as a result of a migration test is given in Table 2.

Place around here Table 1

Place around here Table 2

Materials and methods

PET bottle and pre-form samples

Altogether 67 PET bottle and pre-form samples were collected from European preform and PET bottle manufacturers, each with different raw materials, additives or 
recyclate source. The samples were supplied directly after manufacture. Information about the virgin material supplier, the recyclate manufacturer and the recyclate content as well as the use of oxygen or acetaldehyde scavengers was provided by the bottle or pre-form manufacturers in all cases.

\section{Determination of antimony concentration in PET materials}

$200 \mathrm{mg}$ of the PET bottle wall or pre-form material was treated with $8 \mathrm{ml}$ conc. nitric acid for $15 \mathrm{~min}$ at $200{ }^{\circ} \mathrm{C}$ in a microwave-assisted digestion (similar to EN 13656). Subsequently the concentration of antimony was determined quantitatively by ICPMS according to DIN EN ISO 17294-2 (DIN 2003). Calibration was achieved by external calibration with antimony standards. As internal control standards rhodium and rhenium were used. The limit of detection was determined to $1 \mathrm{mg} / \mathrm{kg}$ in the PET material. The antimony concentrations of two bottles were verified by two other testing laboratories.

\section{Determination of antimony migration kinetics into 3\% acetic acid}

To determine the specific migration of antimony into $3 \%$ acetic acid, a commercially available 1.5 I PET softdrink bottle was used. The bottle was supplied from the bottle manufacturer directly after blowing. The antimony bottle wall concentration was determined to $260 \mathrm{mg} / \mathrm{kg}$ by ICP-MS. The thickness of the bottle wall was determined to $0.27 \mathrm{~mm}$. The crystallinity of the investigated bottle was determined by differential scanning calorimetry (DSC) to $43 \%$. The bottle was cut into $5.0 \times 5.0 \mathrm{~cm}$ pieces. The $5.0 \times 5.0 \mathrm{~cm}$ pieces are further cut into $1.0 \times 5.0 \mathrm{~cm}$ stripes. Five stripes of $1.0 \times 5.0 \mathrm{~cm}$ were placed into a steel cell. Glass pellets of $3 \mathrm{~mm}$ diameter were added in order to reduce the dead volume of the extraction cell. The PET material was extracted with a Büchi Speed Extractor E-916 at $30^{\circ} \mathrm{C}$ up to $150{ }^{\circ} \mathrm{C}$. The extraction cells were filled with $3 \%$ acetic acid at a pressure of 100 bar in the extraction cell. After an extraction time of $1 \mathrm{~h}$, the extraction cell was purged into a glass vial. Subsequently the extraction cell was filled and extracted again with $3 \%$ acetic acid. The procedure was repeated every hour up to total extraction time of $4 \mathrm{~h}$. For 


\section{Determination of diffusion coefficients}

The antimony concentrations of the individual solutions at certain time were plotted against the square root of time. From the linear correlation of the diffusion coefficient was determined according to Equation 1. Due to the total immersion of the PET stripes, the surface area was doubled for the calculation of the diffusion coefficients. Together with the edge surface and active surface of the PET samples of $51.62 \mathrm{~cm}^{2}$ was calculated.

\section{Place around here Equation 1}

\section{Migration modelling}

In addition to the experimental migration tests, a migration model based on diffusion coefficient estimation of chemical substances in polymers has been used (Piringer 2000). This model has been validated within the EU project SMT-CT98-7513 (Piringer 2001, Begley 2005). The calculation of the migration was performed using the AKTS SML software version 4.51 (AKTS AG Siders, Switzerland). 


\section{Results}

\section{Antimony concentrations on the European PET bottle market}

PET bottles and pre-forms manufactured from materials of 15 different PET raw material suppliers were investigated within this study regarding their antimony concentration in the PET material. All investigated bottles are intended for the use as soft drink or mineral water bottles in Europe. The investigated samples can be considered as a comprehensive overview over the PET bottles available in Europe. The bottles were supplied from pre-form and/or bottle manufactures. In addition to the pre-forms and bottles manufactured from virgin PET materials, pre-forms and bottles with post-consumer PET re-cyclates from eleven different PET recyclers were investigated. In these cases a worst-case situation was evaluated, because preforms and bottles made from $100 \%$ re-cyclates were investigated in most cases. The $100 \%$ approach was used, because the amount of PET re-cyclates in European softdrink and mineral water bottles varies typically between $10 \%$ and about $50 \%$ and not in every case, the amount of re-cyclates is known by the filling company. PET bottles and pre-forms manufactured from 100\% re-cyclates gave in addition more similar results in comparison to bottles manufactured from virgin PET. The results of the experimentally determined antimony concentrations in the PET bottles and preforms are compiled in Figure 1. As a result, the mean value from all samples was $224 \pm 32 \mathrm{mg} / \mathrm{kg}(\mathrm{n}=67)$. The median was $220 \mathrm{mg} / \mathrm{kg}$. The bottle wall concentrations determined in this study can be assumed as a basis for the migration calculations (see below).

Place around here Figure 1

\section{Determination of the diffusion coefficients of antimony in PET}

The diffusion coefficients of antimony in PET were determined with specific migration kinetics into $3 \%$ acetic acid as food simulant. In order to establish the diffusion coefficient at temperatures above the boiling point of water (or $3 \%$ acetic acid), a 
high pressure migration test was chosen. For that purpose PET bottle wall stipes (surface area of $51.62 \mathrm{~cm}^{2}$ ) were introduced into a steel extraction cell. The PET was total immersed with $3 \%$ acetic acid at a pressure of 100 bar. The samples were extracted for $1 \mathrm{~h}$ at temperatures from $30^{\circ} \mathrm{C}$ up to $150{ }^{\circ} \mathrm{C}$. After the first migration phase, the migration cells were emptied and filled again with $3 \%$ acetic acid. A second migration phase follows which was either $1 \mathrm{~h}$ or $2 \mathrm{~h}$. After the second migration phase, the migrations cells were emptied again. The procedure was repeated up to $4 \mathrm{~h}$ or either $6 \mathrm{~h}$. All migrations solutions were analysed by ICP-MS for the antimony concentrations. The antimony concentration in the bottle wall $\left(\mathrm{C}_{\mathrm{P}, 0}\right)$ was determined by ICP-MS to $260 \mathrm{mg} / \mathrm{kg}$. The results of the migration kinetics are given in Table 3 and Figure 3. As a result of the migration studies Fickian behaviour of the antimony migration from the PET bottle wall into $3 \%$ acetic acid was found in all cases. Fickan migration behaviour means that the square root of time versus the migration follows a linear correlation. From the slope of these linear correlations, the diffusion coefficients could be calculated according to Equation 1. The experimentally determined diffusion coefficients are summarized in Table 3. Below a temperature of $90^{\circ} \mathrm{C}$, the diffusion coefficients could not be determined because the antimony concentrations in the migration solutions were below of the analytical detection limit $(2 \mu \mathrm{g} / \mathrm{kg})$ of the applied ICP-MS method. Therefore the determination of the diffusion coefficients was not possible. The diffusion coefficients of antimony in PET were also determined by Alt et al (2008) between $45^{\circ} \mathrm{C}$ and $150{ }^{\circ} \mathrm{C}$ (Table 3 and Figure 3).

\section{Place around here Equation 2}

From the diffusion coefficients for temperatures between $105^{\circ} \mathrm{C}$ and $150{ }^{\circ} \mathrm{C}$ the activation energy of the diffusion were calculated according to the Arrhenius approach (Equation 2). As a result, the inverse temperature (in K) and the logarithm of the diffusion coefficient result in a linear correlation (Figure 4). From the slope of this correlation the activation energy of diffusion of antimony from the PET bottle wall into $3 \%$ acetic acid was calculated to $189 \mathrm{~kJ} \mathrm{~mol}^{-1}$. Alt et al (2008) has determined activation energy of diffusion of antimony in PET trays of $184 \mathrm{~kJ} \mathrm{~mol}^{-1}$ which is in good agreement with the activation energy found in this study. Due to the fact, that 
the slopes of the logarithm of the diffusion coefficients versus the inverse temperature are similar in both studies, the activation energies of diffusion are very similar within both studies. However, the pre-exponential factor $\mathrm{D}_{0}$ determined in our study $\left(7.510^{12}\right)$ is different from that found by Alt et al $\left(1.010^{14}\right)$. $D_{0}$ is mainly influenced by the surface area and the concentration of the migrant in the PET bottle wall $\left(c_{p, 0}\right)$. Whereas the surface area can be determined very easily, the concentration of the migrant in the PET bottle wall for inorganic compounds is not known exactly. According to Duh (2002), Biros et al (2002) and El-Toufaili et al (2006) the antimony compound present in PET polymer as antimony glycolate complexes (examples are given in Figure 2). Due to the fact, that antimony is determined in the PET bottle wall after digestion, the total amount of antimony is determined. Antimony might be also bound in the PET polymer chain. Polymer bound antimony, however, will not migrate into beverages. In addition, antimony trioxide itself will most probably also contribute a negligible part to the antimony migration. Therefore, the pre-exponential factor determined by Alt et al (2006) is different compared to the $D_{0}$ determined in this study due to most probably a different amount of migration relevant antimony species in the PET materials used for the migration studies.

Place around here Figure 2

Place around here Figure 3

Place around here Figure 4

Place around here Table 3

\section{Modelling of antimony migration}

The activation energy of diffusion can be used for the calculation of the migration of antimony from the bottle wall into the beverages. The applied migration model is based on the Equations 3 and 4 (Crank 1975, Piringer 2000). The term $\left(m_{F, t} / A\right)$ is the surface related migration. The concentration of antimony in the PET material is $C_{P, 0}$, the wall thickness is $d_{p}$ and the density of the polymer is $\rho_{p}$. The packaging geometry 
(volume foodstuff $\mathrm{V}_{\mathrm{F}}$ and volume polymer $\mathrm{V}_{\mathrm{P}}$ ) as well as the partition coefficient $\mathrm{K}_{\mathrm{P}, \mathrm{F}}$ is part of the $\alpha$ factor (Equation 4). The kinetic part is represented by the temperature-dependent diffusion coefficient $D_{p}$. The term $q_{n}$ is a correction factor for the positive square roots of the equation $\tan q_{n}=-\alpha q_{n}$. In conclusion, from the activation energy the diffusion coefficients for antimony in PET can be calculated at any temperature which can be used for the prediction of the antimony migration according to Equation 3.

Place around here Equation 3

Place around here Equation 4

The experimentally determined activation energy of antimony in PET was used for the prediction of the migration of antimony into contact media. Figure 5 shows the results for the calculation of the migration into beverages from the diffusion coefficients at room temperature $\left(23^{\circ} \mathrm{C}, 30^{\circ} \mathrm{C}\right.$ and $\left.40{ }^{\circ} \mathrm{C}\right)$ up to a storage time of $900 \mathrm{~d}$. Due to the fact, that in our study, the activation energy was only determined above the glass transition temperature $\left(T_{g}\right)$, we assumed the activation energy at temperatures below $\mathrm{T}_{\mathrm{g}}$ do not change. The data of Alt et al slightly indicate a different slope of the Arrhenius plot below $\mathrm{T}_{\mathrm{g}}$, but based on this data a clear conclusion is not possible, because the data fit also in one linear regression over the whole temperature range. As a bottle wall concentration of antimony $224 \mathrm{mg} / \mathrm{kg}$ as well as $350 \mathrm{mg} / \mathrm{kg}$ was assumed. $224 \mathrm{mg} / \mathrm{kg}$ represents the mean value of the antimony bottle wall concentration found in this study. $350 \mathrm{mg} / \mathrm{kg}$ of antimony in the PET bottle wall is the worst case of the antimony concentration (BfR 2010). It should be noted here, that due to migration theory (Equation 3) the concentration of antimony is directly proportional to the migration at certain contact conditions. E.g. if the antimony concentration in the bottle wall is e.g. by a factor of two lower than $350 \mathrm{mg} / \mathrm{kg}$, the migration at a certain contact time is reduced by the same factor. According to the discussion above, the applied concentration of antimony in the PET bottle can be considered as worse case, because parts of the antimony in the PET is polymer bound and has therefore no contribution to the migration of antimony into the beverages. The partition coefficient was assumed to $K=1$, which represents 
good solubility of the migrant in the beverage. $\mathrm{K}=1$ can be therefore considered as the worst case of the antimony migration into beverages.

Place around here Figure 5

\section{Discussion and conclusions}

\section{Prediction of the antimony migration from PET bottles}

The most important parameters for the prediction of the migration of a chemical compound are the concentration of the migrant in the packaging material $\left(c_{p, 0}\right)$, the diffusion coefficient (D) of the chemical species in the polymer as well as the partition coefficient $(\mathrm{K})$ between the polymer and the contact media (Equation 3). The partition coefficient, however, plays in the case of PET a minor role because the equilibrium is not reached assuming typical a shelf life of beverages. This is due to the low diffusivity of the PET polymer (Franz and Welle 2008), which means that for the prediction of the antimony migration the diffusion coefficients are the most important factors.

The diffusion coefficients were determined for temperatures between $105{ }^{\circ} \mathrm{C}$ and $150{ }^{\circ} \mathrm{C}$. The results of this study indicate that the migration of antimony follows a Fickian behaviour. From the temperature dependence of the diffusion coefficients, the activation energy of diffusion of antimony in the PET bottle was determined to be $189 \mathrm{~kJ} \mathrm{~mol}^{-1}$. This is in good agreement with literature data for the antimony migration of $184 \mathrm{~kJ} \mathrm{~mol}^{-1}$ in a PET microwave tray. The activation energies were subsequently used for the calculation of the migration of antimony from the PET bottle wall into beverages under different conditions (Figure 5). With respect to food safety and consumer protection, the lower and therefore more conservative activation energy of $184 \mathrm{~kJ} \mathrm{~mol}^{-1}$ was used for the prediction of the antimony migration. In a first scenario, a bottle wall concentration of $224 \mathrm{mg} / \mathrm{kg}$ was assumed. From this a maximum concentration of about $0.9 \mu \mathrm{g} / \mathrm{kg}$ can be calculated after a storage time of $300 \mathrm{~d}$ at $23^{\circ} \mathrm{C}\left(\mathrm{C}_{\mathrm{P}, 0}=224 \mathrm{mg} / \mathrm{kg}\right)$ for a $500 \mathrm{ml}$ PET bottle. In a second scenario, migration was calculated for a bottle wall concentration of 
$350 \mathrm{mg} / \mathrm{kg}$, which is the maximum concentration of antimony specified according to the German BfR recommendations (BfR 2010).

As a result, the antimony migration even under worst case considerations is far below the specific migration limits of antimony of $40 \mu \mathrm{g} / \mathrm{kg}$ given by European packaging legislation. Under realistic storage conditions, this migration limit can never be reached. The migration values are calculated for two different bottle volumes $(500 \mathrm{ml}$ and $1500 \mathrm{ml})$. Larger PET bottles will lead to a lower antimony migration due to the more favourable surface/volume ratio, which result in a factor 1.43 higher antimony concentration in a $500 \mathrm{ml}$ PET bottle in comparison to a $1500 \mathrm{ml}$ bottle under otherwise equal contact conditions. Under realistic room temperature storage conditions (e.g. $23^{\circ} \mathrm{C}$ ), the lowest drinking water limit $(5 \mu \mathrm{g} / \mathrm{kg}$ ) can also not be exceeded (calculated for storage times up to about $900 \mathrm{~d}$ ).

The literature data compilation in Table 2 gives an overview of the antimony migration studies from PET bottles beverages published over the last 10 to 15 years. The data show that the antimony concentrations did not significantly change over the last decade. From the literature data given in Table 2 it is hard to derive, how many different mineral water, softdrink and juices samples were investigated within the last 10 to 15 years. But the amount is definitively several hundreds of beverage bottles. The samples are coming from many different countries all over the world. However, not in every case it is clear if PET bottles were investigated. On the other hand, most of the literature studies were published from 2000 to 2010. It is therefore most likely that the majority of the investigated mineral water and soft drinks are packaged in PET. Most of the samples were drawn from local markets and the filling date as well as the storage conditions are not or only roughly known. In addition, the bottle wall concentration of antimony was not determined in most cases, which makes a comparison of the results of different migration studies difficult. However, most probably the bottle wall concentrations are in a similar range as found in this study and as given in Figure 1 or Table 1. The storage time before analysing is most probably only a few months. Assuming a storage time of only a few months at room temperature before analysing, the antimony concentrations found in the literature are in good agreement with the calculated data from this study, where a storage of a 
beverage at $23^{\circ} \mathrm{C}$ up to one year would lead to a migration below of about $1 \mu \mathrm{g} / \mathrm{kg}$. The calculated migration in this study (Figure 5) is also in good agreement with published data (e.g. Figure 2 in Keresztes et al 2009). Keresztes et al found that an antimony concentration of about $1 \mu \mathrm{g} / \mathrm{kg}$ in a 1.5 I PET bottle after storage of $950 \mathrm{~d}$ at room temperature.

In a very recent study, Hansen et al (2010) found antimony concentrations up to about $14 \mu \mathrm{g} / \mathrm{kg}$ in red juices. The authors investigated ready to drink juices or cordials, which should be diluted with water prior to consumption. It is interesting to note, that the highest concentrations $(4 \mu \mathrm{g} / \mathrm{kg}$ to $8 \mu \mathrm{g} / \mathrm{kg}$ ) found by Hansen et al are coming from one specific brand packed in completely different packaging materials e.g. PET, cardboard and glass In addition, the highest concentration was found in the glass packed juice. Therefore, the antimony concentrations found by Hansen et al (2010) cannot be related to the packaging material but to the juice itself,. This conclusion which was also taken into consideration by Hansen et al, was supported by the fact, that the concentrations of antimony in cordials (before dilution) were significantly higher than the ready to drink juices. Cordials have to be concentrated which increases also the amount of inorganic compounds in the juice. In conclusion, the antimony contamination found by Hansen et al (2010) occurs in the juices before filling and is due to another contamination way. The migration of antimony from the PET bottle wall plays here a minor role.

\section{Consumer safety considerations}

It is very noteworthy that, as a result of the literature study, no single antimony concentration of the reported beverage samples bottled in PET exceeded the lowest drinking water concentration limit of $5 \mu \mathrm{g} / \mathrm{kg}$. Furthermore, all mean or median values are found below $1 \mu \mathrm{g} / \mathrm{kg}$. The specific migration limit for antimony of $40 \mu \mathrm{g} / \mathrm{kg}$ for bottled water set by food packaging legislation in Europe is far above any of the reported beverage samples covered by our literature search.

According to the extremely low diffusion coefficients of antimony species in PET at room temperature and somewhat elevated temperature up to $40^{\circ} \mathrm{C}$, the resulting 
migration is extremely low (compare Figure 5). For example, the $5 \mu \mathrm{g} / \mathrm{kg}$ drinking water limit will be reached after about 10 years storage of a PET packed beverage (500 ml, $c_{p, 0}=350 \mathrm{mg} / \mathrm{kg}$, worst case scenario). It is interesting to note, that the equilibrium after such a long room temperature storage is still not established. At $40{ }^{\circ} \mathrm{C}$ the $40 \mu \mathrm{g} / \mathrm{kg}$ packaging threshold limit is reached under the above mentioned worst case conditions after about 12 years. At $80{ }^{\circ} \mathrm{C}$ the storage time for establishing a migration of $40 \mu \mathrm{g} / \mathrm{kg}$ is significantly reduced to about $33 \mathrm{~h}$, however, still far above typical hot fill conditions of about a only few minutes at $80^{\circ} \mathrm{C}$. The results of our study substantiate as a matter of fact that the European specific migration limit of $40 \mu \mathrm{g} / \mathrm{kg}$ can never be exceeded in PET bottled beverages even when they were stored over years under worst conditions of e.g. $40{ }^{\circ} \mathrm{C}$ and even at higher technological relevant antimony levels in PET. This conclusion leads immediately to another consequence: antimony compliance testing on PET bottles for beverages and fatty liquids including edible oils is superfluous. This conclusion is complementary to one of our previous studies (Störmer et al 2004) on the migration behaviour of PET with regard to PET monomers and concerning overall migration. In this study we concluded that compliance testing on PET with regard to PET monomers and overall migration is unnecessary because the specified migration limits can never be exceeded by PET materials which are today on the market. Migration modelling considerations can replace here migration testing.

WHO (WHO 2003) has set a tolerable daily intake (TDI) value for antimony of $6 \mu \mathrm{g}$ antimony per $\mathrm{kg}$ body weight. This would translate into $360 \mu \mathrm{g}$ intake for an adult with $60 \mathrm{~kg}$ body weight. The Swiss BAG (BAG 2005) came to the conclusion that the concentrations of antimony found in bottled mineral water samples can be considered as safe, because a consumption of $3 \mathrm{I}$ of a mineral water per day with $1.2 \mu \mathrm{g} / \mathrm{kg}$ antimony which was the highest value found in the BAG study will result in only $1 \%$ of the TDI. Therefore the migrated amounts of antimony relative to the accepted tolerable daily intake (TDI) show that exposure is currently not of toxicological concern (BAG 2005). The results of our study are not only fully supportive to this conclusion which is based on analytical survey data but allow furthermore the prospective conclusion that as long as PET materials are 
manufactured with current levels of antimony, exposure from PET bottles through beverages and edible oils would be less than $1 \%$ of the current TDI. Finally, having substantiated such low antimony levels in PET bottled beverages the above addressed question on estrogenic effects caused by PET bottles appears to be groundless.

\section{Acknowledgement}

Thanks are due to Dominik Fiedler, Manuel Huber, Annika Seiler, Veronika Wildgruber and Gerd Wolz (Fraunhofer IVV) for experimental contributions and fruitful discussions. Information from Dr. Yoko Kawamura from the National Institute of Health Sciences in Tokyo on the Japanese PET market is gratefully acknowledged.

\section{Literature}

Alt A, Haldimann M, Dudler V. 2008. Diffusion coefficient of antimony catalysts in polyethylene terephthalate (PET) materials. Poster Presentation. $4^{\text {th }}$ International Symposium on Food Packaging - Scientific Developments Supporting Safety and Quality, 19.-21. November 2008, Praque, Czech Republic.

Baba A, Erees FS, Hicönmez, Cam S, Özdilek. 2008. An assessment of the quality of various bottle mineral water marketed in Turkey. Environmental Monitoring and Assessment 139:277-285.

BAG 2005. Antimon in Mineralwasser: Beurteilung des Gesundheitsrisikos. Bulletin 44/05. Bundesamt für Gesundheit. Switzerland. 796-797.

Begley TH, Hollifield HC. 1990. Evaluation of polyethylene terephthalate cyclic trimer migration from microwave food packaging using temperature-time profiles. Food Additives and Contaminants. 7:339-346.

Begley TH, Biles JE, Cunningham C, Piringer O. 2004. Migration of a UV stabilizer from polyethylene terephthalate (PET) into food simulants. Food Additives and Contaminants 21:1007-1014. 
Begley T, Castle L, Feigenbaum A, Franz R, Hinrichs K, Lickly T, Mercea P, Milana M, O'Brien A, Rebre S, Rijk R, Piringer O. 2005. Evaluation of migration models that might be used in support of regulations for food-contact plastics. Food Additives and Contaminants 22:73-90.

BfR 2010. Recommendation of the Federal Institute of Risk Assessment (BfR). XVII. Polyterephthalsäurediolester, 01.01.2010.

Biros SM, Bridgewater BM, Villeges-Estrada A, Tanski JM, Parkin G. 2002. Antimony Ethylene Glycolate and Catecholate Compounds: Structural Characterization of Polyesterification Catalysts. Inorganic Chemistry 41(15):4051-4057.

Canada 2008. Guidelines for Canadian Drinking Water Quality - Summary Table prepared by the Federal-Provincial-Territorial Committee on Drinking Water of the Federal-Provincial-Territorial Committee on Health and the Environment.

Choe SY, Kim SJ, Kim HG, Lee JH, Choi Y, Lee H, Kim Y. 2003. Evaluation of estrogenicity of major heavy metals. Science of the Total Environment 312:15-21.

Crank J. 1975. The mathematics of diffusion. Oxford Universsity Press. ISBN 0-19$853411-6$

Dabeka RW, Conacher HBS, Lawrence JF, Newsome WH, McKenzie A, Wagner HP, Chadha RKH, Pepper K. 2002. Survey of bottled drinking waters sold in Canada for chlorate, bromide, bromate, lead, cadmium and other trace elements. Food Additives and Contaminants 19(8):721-732.

DIN 2003. Water quality - Application of inductively coupled plasma mass spectrometry (ICP-MS) - Part 2: Determination of 62 elements (ISO 17294-2:2003)

Duh B. 2002. Effect of antimony catalyst on solid-state polycondensation of poly(ethylene terephthalate). Polymer 43:3147-3154.

El-Toufaili FA, Feix G, Reichert KH. 2006. Mechanistic investigations of antimonycatalyzed polycondensation in the synthesis of poly(ethylene terephthalate). Journal of Polymer Science, Part A: Polymer Chemistry 44(3):1049-1059. 
EU 2002. European Commission Directive 2002/72/EC of 6 August 2002 relating to plastic materials and articles intended to come into contact with foodstuffs. Last amendment: Commission Directive 2008/39/EC of 6 March 2008.

EU 2003. European Commission Directive 2003/40/EC of 16 May 2003 establishing the list, concentration limits and labelling requirements for the constituents of natural mineral waters and the conditions for using ozone-enriched air for the treatment of natural mineral waters and spring waters.

Ewender J, Franz R, Mauer A, Welle F. 2003, Determination of the migration of acetaldehyde from PET bottles into non-carbonated and carbonated mineral water. Deutsche Lebensmittel-Rundschau 99(6):215-221.

Fiket Z, Roje V, Mikac N, Kniewald G. 2007. Determination of arsenic and other trace elements in bottled waters by high resolution inductively coupled plasma mass spectrometry. Croatica Chemica Acta 80(1):91-100.

Fordham PJ, Gramshaw JW, Crews HM, Castle L. 1995. Element residues in food contact plastics and their migration into food simulants, measured by inductively coupled plasma-mass spectrometry. Food Additives and Contaminants 12(5):651669.

Franz R, Welle F. 2008. Migration measurement and modelling from poly(ethylene terephthalate) (PET) into soft drinks and fruit juices in comparison with food simulants. Food Additives and Contaminants 25(8):1033-1046.

Güler C. 2007. Evaluation of maximum contaminant levels in Turkish bottled drinking waters utilizing parameters reported on manufacturer's labelling and governmentissued production licenses. Journal of Food Composition and Analysis 20:262-272.

Haldimann M, Blanc A, Dudler V. 2007. Exposure to antimony from polyethylene terephthalate (PET) trays used in ready-to-eat meals. Food Additives and Contaminants 24(8):860-868. 
Hansen HR, Pergantis SA. 2006. Detection of antimony species in citrus juices and drinking water stored in PET containers. Journal of Analytical Atomic Spectrometry 21:731-733.

Hansen C, Tsirigotaki A, Bak SA, Pergantis SA, Stuerup S, Gammelgaard B, Hansen HR. 2010. Elevated antimony concentrations in commercial juices. Journal of Environmental Monitoring 12:822-824.

Japan 2003. Drinking water quality standards, Ministry of Health, Labour and Welfare, May 2003.

JETRO 2009. Japan External Trade Organisation. Specification and standards for food, food additives etc. under the food sanitation act (abstracts) 2008, January 2009.

Keresztes S, Tatar E, Mihucz VG, Virag I, Majdik C, Zaray G. 2009. Leaching of antimony from polyethylene terephthalate (PET) bottles into mineral water. Science of the Total Environment 407:4731-4735.

Krachler M, Shotyk W. 2009. Trace and ultratrace metals in bottled waters: Survey of sources worldwide and comparison with refillable metal bottles. Science of the Total Environment 407:1089-1096.

Misund A, Frengstad B, Siewers U, Reimann C. 1999. Variation of 66 elements in European bottled mineral waters. Science of the Total Environment 243/244:21-41.

Nishioka K, Hirahara A, Iwamoto E. 2002. Determination of antimony in polyethylene terephthalate bottles by graphite furnace atomic absorption spectrometry using microwave sample preparation. Kenritsu Hiroshima Joshi Daigaku Seikatsu Kagakubu Kiyo 8:35-42.

Ohkado Y, Kawamura Y, Mutsuga M, Tamura H, Tanamoto K.2005. Metals in recycled polyethylene terephthalate and discrimination method for its use. Shokuhin Eiseigaku Zasshi 46(3):109-115.

Piringer OG, Baner AL, (editors). 2008. Plastic Packaging - Interactions with Food and Pharmaceuticals. Wiley-VCH, Weinheim, ISBN 978-3-527-31455-3. 
Piringer O, Hinrichs K. 2001. Evaluation of migration models. Final Report of the EUproject contract SMT-CT98-7513, Brussels.

Plastics Europe 2008. Business data and charts 2007 - Status September 2008 by Plastics Europe Market Research Group (PEMRG). Available online at http://www.plasticseurope.org.

Reimann C, Birke M, Filzmoser P. 2010. Bottled drinking water: Water contamination from bottle materials (glass, hard PET, soft PET), the influence of colour and acidification. Applied Geochemistry 25(7):1030-1046.

Rosborg I, Nihlgard B, Gerhardsson L, Gernersson ML, Ohlin R, Olsson T. 2005. Concentrations of inorganic elements in bottled waters on the Swedish market. Environmental Geochemistry and Health 27:217-227.

Sax L. 2009. Polyethylene terephthalate may yield endocrine disruptors. Environmental Health Perspectives 118(4):445-448.

Shotyk W, Krachler M, Chen B. 2006. Contamination of Canadian and European bottled waters with antimony from PET containers. Journal of Environmental Monitoring 8:288-292.

Shotyk W, Krachler M. 2007. Contamination of bottled waters with antimony leaching from polyethylene terephthalate (PET) increases upon storage. Environmental Science and Technology 41:1560-1563.

Soares EP, Saiki M. 2009. Application of radiometric method for element migration determination from plastic packaging to food. Journal of Radioanalytical and Nuclear Chemistry 280(2):411-413

Soupioni MJ, Symeopoulos BD, Papaefthymion HV. 2005. Determination of trace elements in bottle water in Greece by instrumental and radiochemical neutron activation analysis. Journal of Radioanalytical and Nuclear Chemistry 268(3):441444. 
Störmer A, Franz R, Welle F. 2004. New Concepts for Food Law Compliance Testing of Polyethylene Terephthalate Bottles. Deutsche Lebensmittel-Rundschau 100(2):4752.

Takahashi Y, Sakuma K, Itai T, Zengh G, Mitsunobu S. 2008. Specification of antimony in PET bottles from Japan and China by X-ray absorption fine structure spectrometry. Environmental Science and Technology 42:9045-9050.

Ulrich N. 2000. Determination of antimony species with fluoride as modifier and flow injection hydride generation inductively-coupled plasma emission spectrometry. Analytica Chimica Acta 417:201-209.

US EPA 2009. National primary drinking water regulations. United States Environmental Protection Agency, 2009. Code of Federal Regulations, 40 CFR Part 141.

Westerhoff P, Prapaipong P, Shock E, Hillaireau A. 2008. Antimony leaching from polyethylene terephthalate (PET) plastic used for bottled drinking water. Water Research 42:551-556.

WHO 2003. Antimony in drinking water. Geneva: World Health Organization. WHO/SDE/WSH/03.04/74.

Zucchi OLAD, Moreira S, Salvador MJS, Santos LL. 2005. Multielement analysis of soft drinks by X-ray fluorescence spectrometry. Agricultural and Food Chemistry 53:7863-7869. 
Table 1: Literature data for antimony concentrations determined in PET bottles

\begin{tabular}{|c|c|}
\hline Determined antimony concentrations & Reference \\
\hline $160 \mathrm{ppm}$ and $230 \mathrm{ppm}(\mathrm{n}=2)$ & Fordham et al 1995 \\
\hline $\begin{array}{l}168 \mathrm{ppm} \text { to } 216 \mathrm{ppm}(\mathrm{n}=6) \\
58 \mathrm{ppm}(\mathrm{n}=1)^{[\mathrm{aa}]} \\
<2 \mathrm{ppm}(\mathrm{n}=2)\end{array}$ & Nishioka et al 2002 \\
\hline $\begin{array}{l}188 \mathrm{ppm}^{[\mathrm{b}} 268 \mathrm{ppm} \text { (pellets, } \mathrm{n}=6 \text { ) } \\
<2 \mathrm{ppm}^{\mathrm{b}]} \text { (pellets, } \mathrm{n}=4 \text { ) } \\
189 \mathrm{ppm} \text { to } 264 \mathrm{ppm} \text { (bottles, } 11 \text { ) } \\
<2 \mathrm{ppm} \text { (bottles, } \mathrm{n}=7 \text { ) }\end{array}$ & Ohkado et al 2005 \\
\hline $154 \mathrm{ppm}$ to $275 \mathrm{ppm}(\mathrm{n}=5)^{[\mathrm{d}]}$ & Takahashi et al 2008 \\
\hline $213 \pm 35 \mathrm{ppm}(\mathrm{n}=9)$ & Westerhoff et al 2008 \\
\hline $210 \mathrm{ppm}$ to $290 \mathrm{ppm}(\mathrm{n}=10)$ & Keresztes et al 2009 \\
\hline
\end{tabular}


Table 2: Literature data for antimony concentrations determined in bottled beverages and food simulants

\begin{tabular}{|c|c|c|c|}
\hline Investigated samples & Determined antimony concentrations & Remarks & Reference \\
\hline PET pellets & $\begin{array}{l}\text { Individual conc. } 3 \% \text { acetic acid ( } 10 \mathrm{~d} \text { at } \\
\left.40{ }^{\circ} \mathrm{C}\right): 2.7 \mathrm{ppb} \text { and } 1.2 \mathrm{ppb}, 3 \% \text { acetic } \\
\text { acid }\left(2 \mathrm{~h} \text { at } 100{ }^{\circ} \mathrm{C}\right): 3.9 \mathrm{ppb} \text { and } 2.6 \mathrm{ppb} \text {, } \\
15 \% \text { ethanol }\left(10 \mathrm{~d} \text { at } 40^{\circ} \mathrm{C}\right): 2.3 \mathrm{ppb} \text { and } \\
1.1 \mathrm{ppb} \text {, olive oil }<0.01 \mathrm{ppb} \text { (both } \\
\text { conditions) }\end{array}$ & $\begin{array}{l}3 \mathrm{~g} \text { of PET pellets were totally } \\
\text { immersed with } 20 \mathrm{ml} \text { of food } \\
\text { simulant. }\end{array}$ & Fordham et al 1995 \\
\hline $\begin{array}{l}56 \text { European bottled } \\
\text { mineral water brands }\end{array}$ & $\begin{array}{l}\text { Individual conc. } 0.003 \mathrm{ppb} \text { to } 1.06 \mathrm{ppb} \\
\text { median conc. } 0.17 \mathrm{ppb}\end{array}$ & $\begin{array}{l}\text { Packing materials were not } \\
\text { specified }\end{array}$ & Misund et al 1999 \\
\hline $\begin{array}{l}\text { One orange juice } \\
\text { sample }\end{array}$ & Conc. $2.2 \mathrm{ppb}$ & Packing material was not specified & Ulrich 2000 \\
\hline $\begin{array}{l}42 \text { Mineral water } \\
\text { brands from Canada } \\
\text { (199 different } \\
\text { samples) }\end{array}$ & $\begin{array}{l}\text { Mineral water: average conc. } 0.32 \mathrm{ppb}(\mathrm{n} \\
=42) \text {, spring water: average conc. } \\
0.30 \mathrm{ppb}(\mathrm{n}=102) \text {, distilled water: } \\
\text { average conc. } 0.17 \mathrm{ppb}(\mathrm{n}=25) \text {, soda } \\
\text { water: average conc. } 0.29 \mathrm{ppb}(\mathrm{n}=19), \\
\text { tap water: average conc. } 0.17 \mathrm{ppb}(\mathrm{n}= \\
11) \text {, individual conc. } 0.03 \mathrm{ppb} \text { to } 1.31 \mathrm{ppb}\end{array}$ & $\begin{array}{l}\text { Packing materials were not } \\
\text { specified. Samples drawn } \\
\text { December } 1995 \text { to February } 1996\end{array}$ & Dabeka et al 2002 \\
\hline $\begin{array}{l}\text { Food simulants } 3 \% \\
\text { acetic acid and } 95 \% \\
\text { ethanol }\end{array}$ & $\begin{array}{l}\text { Individual conc. in } 3 \% \text { acetic acid: } \\
0.15 \mu \mathrm{g} \mathrm{dm}{ }^{2} \text { to } 0.57 \mu \mathrm{g} \mathrm{dm} \mathrm{dm}^{2}(\mathrm{n}=7, \\
\text { assuming a } 1 \text { I bottle with } 6 \mathrm{dm}^{2} \text { surface } \\
\text { area will result in concentrations between } \\
0.90 \mathrm{ppb} \text { to } 3.42 \mathrm{ppb}) \text {, in } 95 \% \text { ethanol: } \\
<0.3 \mu \mathrm{g} \mathrm{dm}\end{array}$ & $\begin{array}{l}\text { Storage for } 10 \mathrm{~d} \text { at } 40{ }^{\circ} \mathrm{C} \text {, surface } \\
\text { volume ratio of } 2 \mathrm{dm}^{2} \text { for } 100 \mathrm{ml} \\
\text { simulant }\end{array}$ & Störmer et al 2004 \\
\hline Mineral water & $\begin{array}{l}\text { Average conc. (PET): } 0.43 \mathrm{ppb}(\mathrm{n}=49) \\
\text { average conc. (glass): factor } 3.5 \text { lower }\end{array}$ & $\begin{array}{l}\text { Samples were packed in glass and } \\
\text { PET. }\end{array}$ & BAG 2005 \\
\hline
\end{tabular}




\begin{tabular}{|c|c|c|c|}
\hline Investigated samples & Determined antimony concentrations & Remarks & Reference \\
\hline & than PET $(n=20)$ & & \\
\hline $\begin{array}{l}48 \text { Bottled waters from } \\
\text { the Swedish market }\end{array}$ & $\begin{array}{l}\text { Individual conc. } 0.01 \mathrm{ppb} \text { to } 0.80 \mathrm{ppb} \text {; } \\
\text { median conc. } 0.32 \mathrm{ppb}\end{array}$ & $\begin{array}{l}\text { Packing materials were not } \\
\text { specified. }\end{array}$ & Rosborg et al 2005 \\
\hline $\begin{array}{l}\text { Four brands of bottled } \\
\text { water from Greece }\end{array}$ & $\begin{array}{l}\text { individual conc. } 0.005 \mathrm{ppb} \text { to } 0.06 \mathrm{ppb} \\
\text { average value } 0.02 \pm 0.02 \mathrm{ppb}\end{array}$ & $\begin{array}{l}\text { Packing materials were not } \\
\text { specified. }\end{array}$ & Soupioni et al 2005 \\
\hline $\begin{array}{l}17 \text { Softdrinks from } \\
\text { Brazil }\end{array}$ & $\begin{array}{l}3 \text { samples between } 1.95 \mathrm{ppm} \text { and } \\
4.11 \mathrm{ppm}(!) \text {. All other below the detection } \\
\text { limit. }\end{array}$ & $\begin{array}{l}\text { All samples were packed in PET } \\
\text { bottles. Detection limit not given! } \\
\text { Antimony concentrations in the } \\
\text { PET bottles are in the range of } \\
25 \text { ppm to } 138 \text { ppm. } \\
\text { NOTE: The values are by a factor } \\
1000 \text { higher than all other values. } \\
\text { Most probably the concentrations } \\
\text { should be } 1.95 \text { ppb and } 4.11 \text { ppb, } \\
\text { not ppm! }\end{array}$ & Zucchi et al 2005 \\
\hline $\begin{array}{l}\text { Citrus flavoured } \\
\text { softdrinks }\end{array}$ & $\begin{array}{l}\text { Individual conc. in PET } 0.24 \mathrm{ppb} \text { to } \\
1.05 \mathrm{ppb}(\mathrm{n}=35) \text {, cardboard: } 0.07 \mathrm{ppb}(\mathrm{n} \\
=4) \text {, glass: } 0.28 \mathrm{ppb} \text { to } 0.30 \mathrm{ppb}(\mathrm{n}=3) \\
\text { aluminium: } 0.24 \mathrm{ppb} \text { to } 0.56 \mathrm{ppb}(\mathrm{n}=3)\end{array}$ & $\begin{array}{l}\text { Samples bottled in glass, } \\
\text { cardboard, PET and aluminium } \\
\text { cans }\end{array}$ & Hansen and Pergantis 2006 \\
\hline $\begin{array}{l}15 \text { Mineral water } \\
\text { brands from Canada } \\
\text { and } 48 \text { brands from } \\
\text { Europe }\end{array}$ & $\begin{array}{l}\text { Individual conc. Canada: } 0.11 \mathrm{ppb} \text { to } \\
0.38 \mathrm{ppb}(\mathrm{n}=21) \text {, Germany: } 0.25 \mathrm{ppb} \text { to } \\
0.55 \mathrm{ppb} \text {; Median from Europe: } 0.34 \mathrm{ppb} \\
(\mathrm{n}=35)\end{array}$ & $\begin{array}{l}\text { Bottled water in polypropylene } \\
\text { showed significantly lower } \\
\text { antimony concentrations. Three } \\
\text { brands were stored for additional } \\
\text { three months at room temperature } \\
\text { and the antimony migration } \\
\text { increase from } 0.36 \text { ppb to }\end{array}$ & Shotyk et al 2006 \\
\hline
\end{tabular}




\begin{tabular}{|c|c|c|c|}
\hline Investigated samples & Determined antimony concentrations & Remarks & Reference \\
\hline & & 0.63 ppb. & \\
\hline $\begin{array}{l}128 \text { Mineral water } \\
\text { brands from } 28 \\
\text { countries }\end{array}$ & $\begin{array}{l}\text { Individual conc. Japan: } 0.01 \mathrm{ppb} \text { to } \\
1.52 \mathrm{ppb} \text {, median conc. } 0.22 \mathrm{ppb} \text { ( } 69 \\
\text { brands from } 16 \text { countries), highest conc. } \\
2.57 \mathrm{ppb} \text { (brand from Peru) }\end{array}$ & $\begin{array}{l}\text { In most of the cases, the samples } \\
\text { were stored for six months at room } \\
\text { temperature. }\end{array}$ & Shotyk and Krachler 2007 \\
\hline $\begin{array}{l}16 \text { Spring water, } 8 \\
\text { mineral water and } 5 \\
\text { tap water samples } \\
\text { from Croatia }\end{array}$ & Individual conc. $0.02 \mathrm{ppb}$ to $0.51 \mathrm{ppb}$ & $\begin{array}{l}\text { All samples were packed in plastic } \\
\text { containers, the polymer types were } \\
\text { not given. }\end{array}$ & Fiket et al 2007 \\
\hline $\begin{array}{l}189 \text { Brands of bottled } \\
\text { drinking water from } \\
\text { Turkey }\end{array}$ & $\begin{array}{l}\text { Individual conc. between trace amounts } \\
\text { and } 5 \mathrm{ppb}\end{array}$ & $\begin{array}{l}\text { The packaging materials were not } \\
\text { specified. }\end{array}$ & Güler 2007 \\
\hline $\begin{array}{l}\text { PET bottles from } \\
\text { Japan and China }\end{array}$ & $\begin{array}{l}\text { Individual conc. } 0.85 \mathrm{ppb} \text { to } 4.40 \mathrm{ppb}(\mathrm{n}= \\
\text { 9) }\end{array}$ & $\begin{array}{l}0.1 \mathrm{~g} \text { PET in } 2 \mathrm{~g} \text { water stored for } \\
30 \mathrm{~d} \text { and } 45 \mathrm{~d} \text { at } 40^{\circ} \mathrm{C} \text {. }\end{array}$ & Takahashi et al 2008 \\
\hline $\begin{array}{l}\text { Nine brands of bottled } \\
\text { water from the United } \\
\text { States }\end{array}$ & 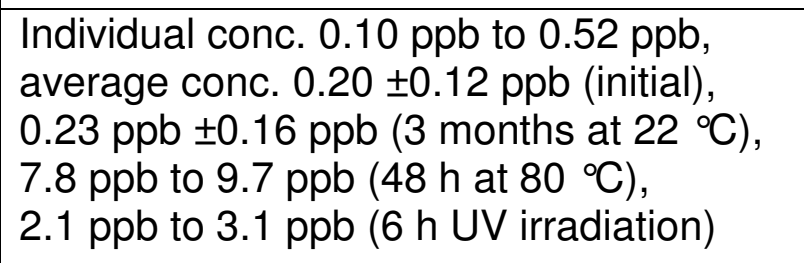 & $\begin{array}{l}\text { All samples were packed in PET } \\
\text { bottles. Migration kinetics data are } \\
\text { given. }\end{array}$ & Westerhoff et al 2008 \\
\hline $\begin{array}{l}15 \text { Bottled mineral } \\
\text { water samples from } \\
\text { Turkey }\end{array}$ & $\begin{array}{l}\text { Individual conc. below the analytical } \\
\text { detection limit of } 1 \mathrm{ppb}\end{array}$ & $\begin{array}{l}\text { Samples drawn in } 2003 \text {. The } \\
\text { packaging materials were not } \\
\text { specified. }\end{array}$ & Baba et al 2008 \\
\hline $\begin{array}{l}\text { Water, juices and } \\
\text { acidic fatty food from } \\
\text { Brazil, Argentina and }\end{array}$ & $\begin{array}{l}\text { Individual conc. softdrinks: } 0.16 \mathrm{ppb} \text { to } \\
1.58 \mathrm{ppb}(\mathrm{n}=24) \text {, juice: } 0.54 \mathrm{ppb} \text { to } \\
0.85 \mathrm{ppb}(\mathrm{n}=3) \text {, acidic fatty food: } 0.75 \text { ( } \mathrm{n}\end{array}$ & $\begin{array}{l}\text { All samples were packed in PET } \\
\text { bottles. Data for HDPE and PP are } \\
\text { below the analytical detection }\end{array}$ & Soares and Saiki 2009 \\
\hline
\end{tabular}




\begin{tabular}{|c|c|c|c|}
\hline Investigated samples & Determined antimony concentrations & Remarks & Reference \\
\hline Portugal & $=1)$, water: $0.41 \mathrm{ppb}$ to $0.85 \mathrm{ppb}(\mathrm{n}=8)$ & limits. & \\
\hline $\begin{array}{l}10 \text { Brands of non- } \\
\text { carbonated and } \\
\text { carbonated mineral } \\
\text { water from Hungarian }\end{array}$ & $\begin{array}{l}\text { Mean conc. for non-carbonated water } \\
0.26 \pm 0.16 \mathrm{ppb}(\mathrm{n}=37) \text {, carbonated } \\
\text { water } 0.40 \pm 0.22 \mathrm{ppb}(\mathrm{n}=29) \text {, highest } \\
\text { conc. } 0.8 \mathrm{ppb} \text {. Highest conc. } 2 \text { ppb after } \\
\text { storage from } 72 \text { h at } 60^{\circ} \mathrm{C} \text {. }\end{array}$ & $\begin{array}{l}\text { All samples packed in PET bottles. } \\
\text { Data for storage at higher } \\
\text { temperatures and under daylight } \\
\text { exposure as well as migration } \\
\text { kinetics data are given. }\end{array}$ & Keresztes et al 2009 \\
\hline $\begin{array}{l}132 \text { Brands of bottled } \\
\text { water from } 28 \\
\text { countries }\end{array}$ & $\begin{array}{l}\text { Individual conc. } 0.001 \mathrm{ppb} \text { to } 2.57 \mathrm{ppb} \text {, } \\
\text { median conc. } 0.33 \mathrm{ppb}\end{array}$ & $\begin{array}{l}\text { All water samples were packed in } \\
\text { plastic (mainly in PET) }\end{array}$ & Krachler and Shotyk 2009 \\
\hline $\begin{array}{l}42 \text { Juice samples of } \\
16 \text { different brands } \\
\text { from Greece, Denmark } \\
\text { and Scotland }\end{array}$ & $\begin{array}{l}\text { Individual conc. } 0.01 \mathrm{ppb} \text { to } 13.6 \mathrm{ppb}(\mathrm{n}= \\
42)\end{array}$ & $\begin{array}{l}\text { Samples packed in glass, PET } \\
\text { bottles and cardboard. Juices were } \\
\text { mainly red fruits juices (black } \\
\text { currant, raspberry, sour cherry, } \\
\text { mint and synthetic caramel). The } \\
\text { highest concentrations of antimony } \\
\text { found in the investigated juices } \\
\text { samples are coming from one } \\
\text { brand (black currant, } 16 \text { samples } \\
\text { of this brand were analysed, } 13 \text { in } \\
\text { PET, } 3 \text { in cardboard). The highest } \\
\text { antimony concentration found in } \\
\text { the study was } 13.6 \text { ppb for a sour } \\
\text { cherry juice produced in Greece } \\
\text { and sold in a glass bottle. }\end{array}$ & Hansen et al 2010 \\
\hline $\begin{array}{l}294 \text { samples of bottled } \\
\text { water (predominantly } \\
\text { mineral water) sold in }\end{array}$ & $\begin{array}{l}\text { median conc. (PET) } 0.33 \mathrm{ppb}(\mathrm{n}=294) \text {, } \\
\text { median conc. (glass) } 0.02 \mathrm{ppb}(\mathrm{n}=294) \text {, } \\
\text { highest conc. (PET, distilled water, } 150 \mathrm{~d} \\
\text { storage) } 0.27 \mathrm{ppb}(\mathrm{n}=126) \text {, highest conc. }\end{array}$ & $\begin{array}{l}294 \text { pairs of water sold in PET as } \\
\text { well as in glass were directly } \\
\text { compared. Subsequently the } \\
\text { bottles were filled with purified }\end{array}$ & Reimann et al 2010 \\
\hline
\end{tabular}




\begin{tabular}{|l|l|l|l|}
\hline Investigated samples & Determined antimony concentrations & Remarks & Reference \\
\hline the European Union & $\begin{array}{l}\text { (glass, distilled water, 150 d storage) } \\
0.45 \mathrm{ppb}(\mathrm{n}=126), \text { median conc. (glass, } \\
\text { distilled water, 150 d storage })<0.002 \mathrm{ppb} \\
(\mathrm{n}=126)\end{array}$ & $\begin{array}{l}\text { water. Migration kinetics data are } \\
\text { given. Also some glass bottles } \\
\text { leach antimony. }\end{array}$ & \\
\hline
\end{tabular}


Table 3: Diffusion coefficients of antimony in PET

\begin{tabular}{|l|l|l|}
\hline $\begin{array}{l}\text { Temperature } \\
{\left[{ }^{\circ} \mathrm{C}\right]}\end{array}$ & $\begin{array}{l}\text { Diffusion coefficient } \\
{\left[\mathrm{cm}^{2} \mathrm{~s}^{-1}\right]} \\
\text { this study }\end{array}$ & Alt et al (2008) \\
\hline 45 & & $1.410^{-16}$ \\
\hline 60 & & $1.010^{-15}$ \\
\hline 75 & & $9.110^{-15}$ \\
\hline 90 & & $2.710^{-13}$ \\
\hline 105 & $3.810^{-14}$ & $4.710^{-12}$ \\
\hline 120 & $1.410^{-12}$ & $3.010^{-11}$ \\
\hline 130 & $2.710^{-12}$ & \\
\hline 135 & & $2.510^{-10}$ \\
\hline 140 & $7.510^{-12}$ & \\
\hline 150 & $3.310^{-11}$ & $3.010^{-9}$ \\
\hline
\end{tabular}

Equation $1: \frac{m}{A}=2 c_{P, 0} \sqrt{\frac{D t}{\pi}}$ 


\section{Page 31 of 36}

Equation 2: $D_{P}=D_{0} e^{-\frac{E_{A}}{R T}}$

Equation 3: $\frac{m_{F, t}}{A}=c_{P, 0} \rho_{P} d_{P}\left(\frac{\alpha}{1+\alpha}\right)\left[1-\sum_{n=1}^{\infty} \frac{2 \alpha(1+\alpha)}{1+\alpha+\alpha^{2} q_{n}^{2}} e^{\left(-D_{P} t \frac{q_{n}^{2}}{d_{P}^{2}}\right)}\right]$

Equation 4: $\alpha=\frac{\frac{V_{F}}{V_{P}}}{K_{P, F}}$ 


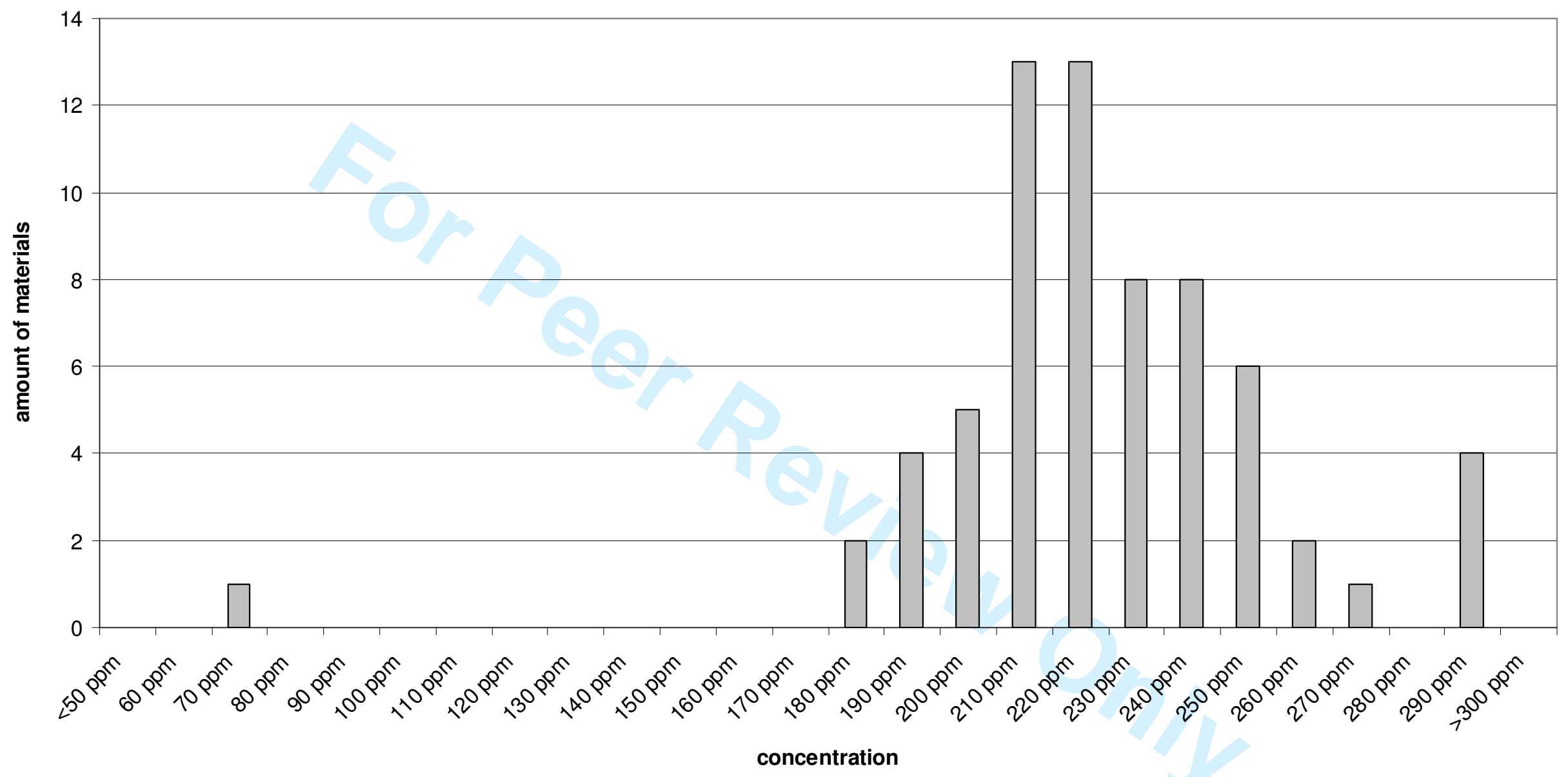

Figure 1: Antimony concentrations in PET beverage bottles and preforms from the European market $(n=67)$ 
<smiles>OCCO[Sb]1OCCO1</smiles>
1<smiles>C1CO[Sb]2OCCO[Sb](O1)OCCO2</smiles>

2

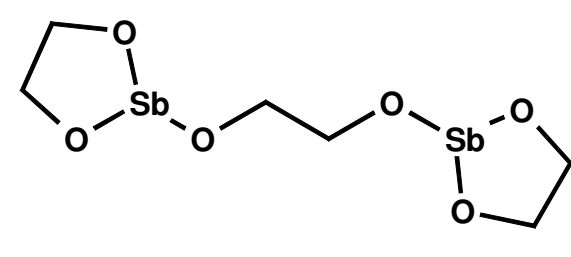

3

Figure 2: Proposed structures for the antimony species in PET 


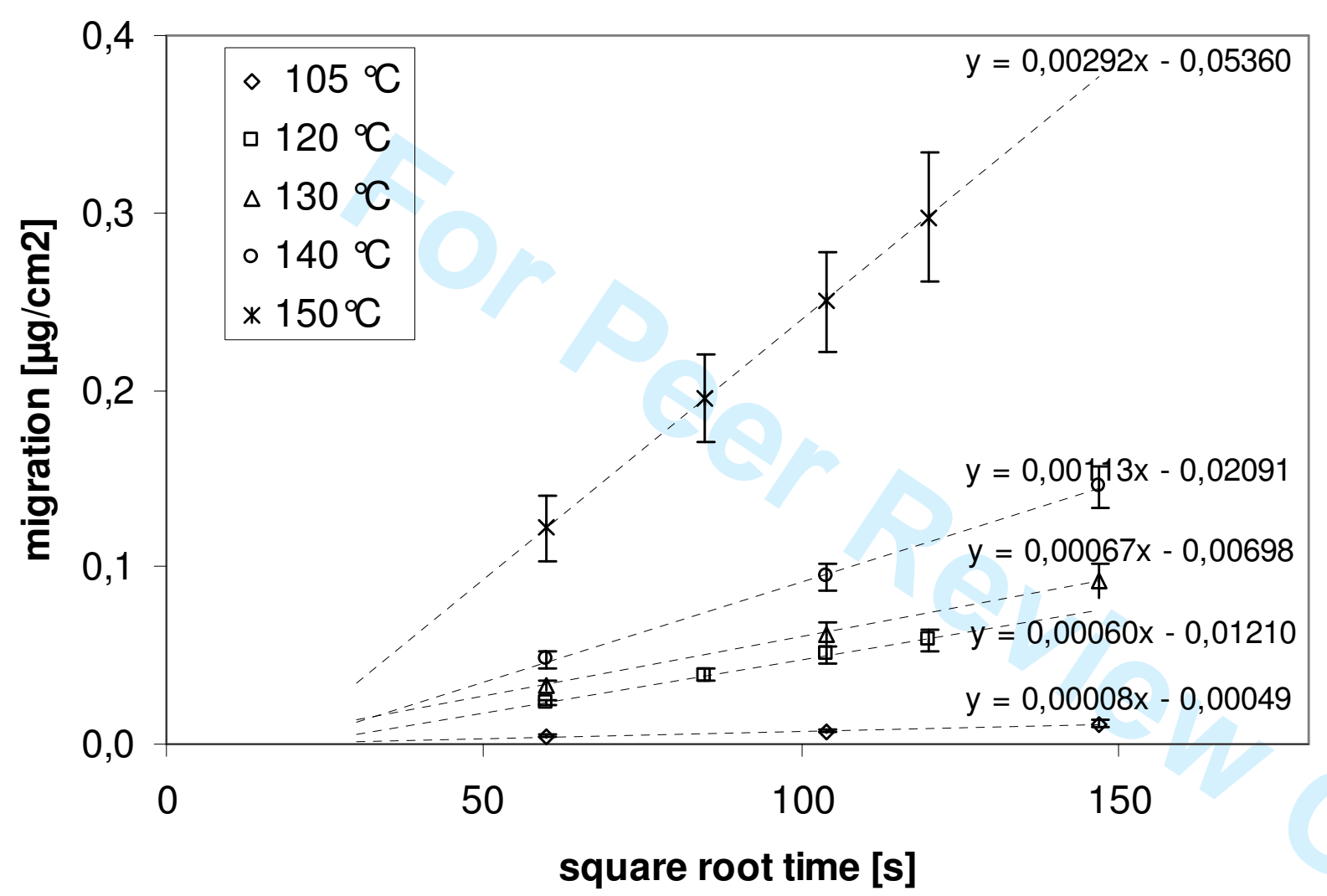

Figure 3: Migration kinetic of antimony from PET bottle into $3 \%$ acetic acid (Büchi Speed Extractor, $\mathrm{C}_{\mathrm{P}, 0}=260 \mathrm{ppm}, \mathrm{A}=51.62 \mathrm{~cm}^{2}, \mathrm{~V}=$ $40 \mathrm{ml})$ 


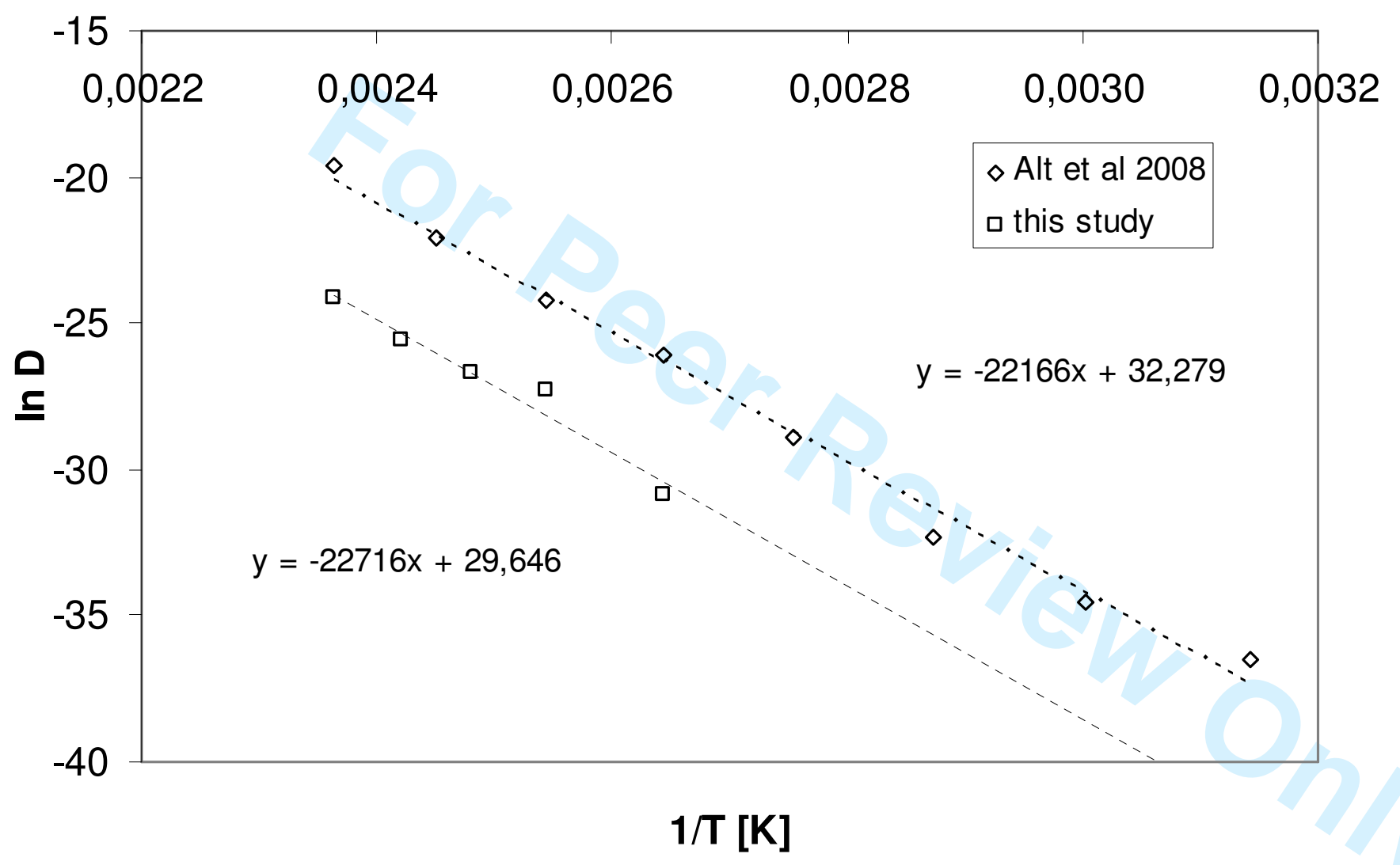

Figure 4: Arrhenius plot of the diffusion coefficients of antimony in PET (Diffusion coefficients from Table 3) 


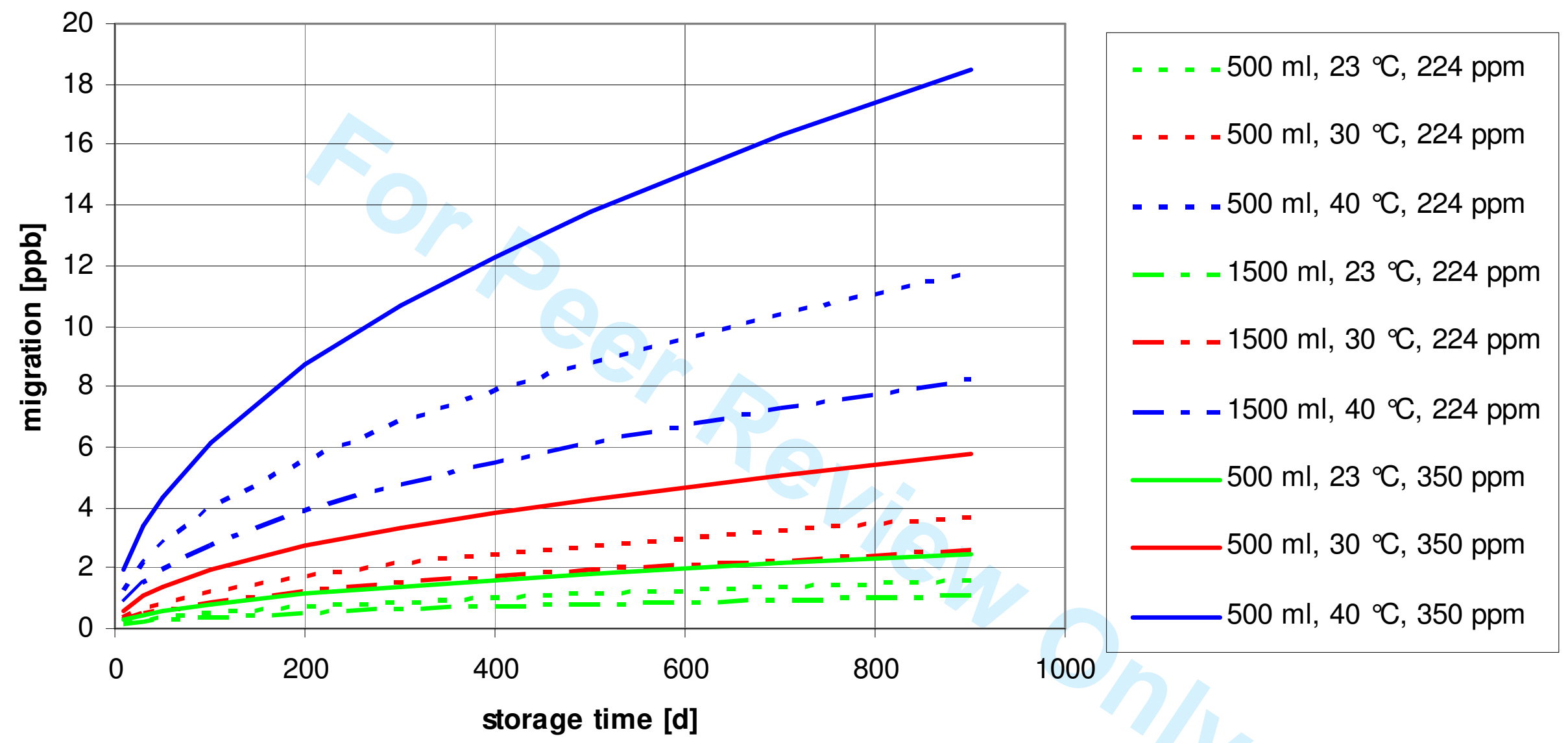

Figure 5: Calculated migration from the PET bottle into beverages as a function of the storage time and storage temperature (bottle wall concentration $C_{P, 0}=224 \mathrm{ppm}$ and $350 \mathrm{ppm}$, activation energy $E_{A}=184 \mathrm{~kJ} \mathrm{~mol}^{-1}, D_{0}=110^{14}, K=1$, internal bottle wall surface $420 \mathrm{~cm}^{2}\left(500 \mathrm{ml}\right.$ bottle) and $880 \mathrm{~cm}^{2}(1500 \mathrm{ml}$ bottle), wall thickness $\mathrm{d}=300 \mu \mathrm{m})$ 